\title{
O PROCESSO ADMINISTRATIVO TRIBUTÁRIO E SUA INFLUÊNCIA NA APURAÇÃO DOS CRIMES CONTRA A ORDEM TRIBUTÁRIA
}

\author{
Marcos José de Araújo Filho \\ Ricardo Wagner Amorim Tavares Filho \\ Especialistas em Direito Tributário (FA7). Advogados. \\ Artigo orientado pelo prof. Ms. Rui Farias (FA7). \\ marcosjose@regev.com.br
}

Sumário: Introdução. 1. Breves considerações sobre o processo tributário. 2. Independência das instâncias: administrativa e criminal. 3. Processo penal independente do término do procedimento administrativo. 4. O processo administrativo tributário e a sua influência na apuração dos crimes contra a ordem tributária. Conclusão.

Resumo: Discorre sobre a interdependência das instâncias administrativa e criminal no que respeita ao processo dos delitos contra a ordem tributária, conforme o ordenamento jurídico brasileiro; tema já pacificado entre juristas e tribunais brasileiros. Em primeiro lugar, analisam-se aspectos gerais acerca do processo tributário e como se dava a independência entre as esferas administrativa fiscal e a penal nos, outrora, conhecidos crimes de sonegação fiscal. Em seguida, desenvolve-se a mudança de paradigma com a edição da lei 9.430 de 27 de dezembro de 1996, trazendo um pressuposto de admissibilidade específico para os crimes contra a ordem tributária, qual seja: o término do procedimento fiscal. Por fim, traça comentários exemplificativos tanto da doutrina como da jurisprudência, para demonstrar a relevância da conexão dessas instâncias.

Palavras-chave: Interdependência. Administração. Crimes.

\section{INTRODUÇÃO}

O objetivo deste estudo é analisar o procedimento/processo administrativo-fiscal e seu prévio exaurimento, a influenciar o processo penal dos delitos contra a ordem tributária.

O processo administrativo tributário contempla o conjunto de normas que disciplinam o regime jurídico processual aplicável às lides tributárias, inexistindo uniformização delas, visto que sua instituição cabe a cada ente federativo.

Antes da edição da Lei 9.430, de 27 de dezembro de 1996, o Processo Penal brasileiro rezava que, independentemente do término da avaliação do processo e procedimento administrativo tributário, a ação penal nos crimes de sonegação fiscal não estava a eles condicionada; não havia nenhuma condição prévia de procedibilidade.

Esse panorama fora alterado principalmente com a vigência do artigo 83 da Lei 9.430/96, que atualmente não traz mais a denominação "crimes de sonegação fiscal”, e sim crimes contra a Ordem Tributária (Lei 8.137/90). 
Art. 83. A representação fiscal para fins penais relativa aos crimes contra a ordem tributária previstos nos arts. $1^{\circ}$ e $2^{\circ}$ da Lei n ${ }^{\circ} 8.137$, de 27 de dezembro de 1990 , e aos crimes contra a Previdência Social, previstos nos arts. 168-A e 337-A do Decreto-Lei $\mathrm{n}^{\circ} 2.848$, de 7 de dezembro de 1940 (Código Penal), será encaminhada ao Ministério Público depois de proferida a decisão final, na esfera administrativa, sobre a exigência fiscal do crédito tributário correspondente. (Redação dada pela Lei n ${ }^{\circ} 12.350$, de 2010)."

O Trabalho configura-se teórico-científico, desenvolvido por meio de pesquisas amparadas na legislação, doutrina e jurisprudência, de forma a demonstrar de maneira objetiva, mas ampla, todo o arcabouço em que se desenvolveu a mudança de entendimento quanto à independência das instâncias administrativa tributária e a criminal no que tange aos delitos contra a Ordem Tributária.

\section{Breves Considerações Sobre o Processo Tributário}

O processo administrativo tributário possui autonomia frente ao processo civil e ao administrativo propriamente dito. Ele é formado pelas normas que disciplinam o regime jurídico processual aplicável às lides tributárias deduzidas perante a Administração Pública. É válido salientar que não há, como no processo judicial, uma uniformização da legislação do processo administrativo tributário para vigorar em todo o território nacional, pois sua instituição cabe a cada ente, conforme a sua competência constitucional concorrente.

O Processo Tributário é um termo amplo que engloba o estudo do Procedimento Administrativo Tributário (fase oficiosa), Processo Administrativo Tributário (fase contenciosa administrativa) e o Processo Judicial Tributário (fase contenciosa judicial).

Vale demonstrar sucintamente as distinções entre procedimento e processo: o mero procedimento ocorre quando houver apenas uma sequência de atos interligados de forma ordenada, previstos em lei, com vistas ao provimento final, prescindindo da participação ou influência de outros sujeitos no objetivo visado. Pode-se citar como exemplo a fiscalização a um contribuinte, que é a fase não litigiosa da atividade administrativa tributária sem nenhuma feição judicante.

Já o processo configura-se numa série de atos que objetivam solucionar uma lide, assegurando-se o contraditório com a participação dos sujeitos no resultado final. O processo tributário pode ser verificado na impugnação de lançamento, indeferimento de compensação ou restituição etc. Em suma, vislumbramos atividades de feições jurisdicionais exercidas atipicamente pelo Poder Executivo.

Os Procedimentos Administrativos são regidos por uma série de princípios, tais como a oficialidade em que a Administração, independentemente de provocação, instaura, impulsiona e conclui seus procedimentos; a inquisitoriedade, pois não há contraditório, dispensando-se a participação do contribuinte; a subordinação hierárquica, já que o poder hierárquico é exercido pelas autoridades superiores precipuamente através de edição de normas infralegais que devem ser obedecidas pelos subordinados, bem como o dever de fundamentação, a cientificação (decorre da publicidade - é direito do contribuinte ser cientificado previamente de todos os atos) e a busca pela verdade real (as presunções devem ser investigadas).

O Processo Administrativo é norteado por vários princípios inerentes ao judicial, como o Devido Processo Legal, a Ampla Defesa e o Contraditório, a Instrumentalidade e Economia Processual, o Duplo Grau de Jurisdição e a Fundamentação das Decisões.

Mas, saliente-se que possui seus princípios específicos, que são: a Utilidade do processo que possui semelhança com a efetividade da tutela jurisdicional (o processo administrativo há de ter um resultado útil e eficaz). Este princípio fundamenta o fato de que o MP não pode 
denunciar o contribuinte por crime contra a ordem tributária, senão depois de decisão final da Administração Tributária; não submissão do órgão julgador ao poder hierárquico - a autoridade administrativa quando exerce a função atípica de julgar é livre para fazê-lo; Verdade material e a Oficialidade, pois a autoridade administrativa deve impulsionar o processo para que se alcance uma conclusão rápida.

O Processo Administrativo Tributário inicia-se, comumente, pela impugnação ao lançamento que possui os efeitos de suspender a exigibilidade do crédito até ulterior decisão definitiva ${ }^{1}$, bem como o de impedir a propositura de ação penal nos crimes contra a ordem tributária antes da manifestação definitiva da autoridade administrativa (objeto de nosso estudo).

Pode-se concluir que há, portanto, vantagens em se utilizar a esfera administrativa, pois muito embora os órgãos julgadores da administração não possuam a independência e a imparcialidade do Judiciário, eles, em regra, agem com mais celeridade em face da menor formalidade e da onerosidade diminuta do processo administrativo fiscal. É válido salientar também que estes julgadores administrativos possuem um maior conhecimento da legislação e das peculiaridades fáticas (já que exercem uma atividade mais específica).

\section{Independência das Instâncias: Administrativa e Criminal}

Nas fiscalizações realizadas por entidades ou órgãos públicos como a Receita Federal, dentre outros, quando detectada a existência de infração administrativa (aí incluída a fiscal), o agente público autua o infrator e, quando observa a existência de elementos que evidenciem também prática de crime, encaminha-os ao órgão próprio para que seja dado início à persecução criminal. É certo que o procedimento administrativo não se encerrou, eis que há a possibilidade do exercício do direito de defesa, assegurado constitucionalmente, até a última instância administrativa.

O entendimento majoritário, antes das Leis $n^{\text {os }} 8.137 / 90$ e 9.430/96, era de que não havia de se esperar o encerramento da instância administrativa para que se desse início à investigação criminal nos crimes de sonegação fiscal, seguida da propositura da ação penal por meio da denúncia, sequenciada pela sentença (condenatória ou absolutória) e por eventual acórdão, formando-se a coisa julgada. Inexistia condição de procedibilidade ou questão prejudicial ou, ainda, qualquer elementar do tipo penal, quanto ao encerramento do procedimento administrativo para efeito no Processo Penal.

Tal posicionamento foi esposado na Súmula 609 do Supremo Tribunal Federal, dispondo que a ação penal nos crimes de sonegação fiscal não estava condicionada a nenhuma condição prévia de procedibilidade.

Ainda na década de 80, Jorge Medeiros da Silva, em análise detida a respeito do assunto, mormente em matéria de crimes tratados nas leis previdenciárias, comentava:

Com respeito às faltas administrativas vale, todavia, mencionar que, quando um fato repercute tanto na esfera administrativa como na penal, os processos correspondentes são totalmente independentes, inexistindo qualquer relação legal entre ambos. Ao ser apurada infração administrativa que, em tese, também possa ser considerada ilícito penal, incumbe à Administração Pública promover as comunicações pertinentes, à época da descoberta da infração, independentemente do desfecho do procedimento administrativo, ou mesmo que este ainda não tenha sido instaurado. (SILVA, 1981, p. 38-39).

\footnotetext{
${ }^{1}$ Art. 151, III da Lei 5.172/66 (Código Tributário Nacional).
} 
A comunicação imediata do agente da administração pública ao responsável pela investigação ou pela deflagração da ação penal é indispensável, mesmo porque, na qualidade de funcionário público no exercício de suas funções, não pode ser tratado como qualquer pessoa do povo, consoante os preceitos dos arts. $5^{\circ}, \S 3^{\circ}$, e 27, ambos do Código de Processo Penal, e, assim, em vez de faculdade, há o dever funcional de realizar tal comunicação.

$\mathrm{Na}$ eventualidade de um mesmo acontecimento repercutir nas esferas administrativa, civil e criminal, como no caso de um servidor público perpetrar a conduta de subtrair bem ou valor da repartição em que exercia suas funções, valendo-se da facilidade da função exercida, três sanções de diferentes naturezas poderão ser aplicadas ao infrator. Para cada instância, a princípio, será instaurado procedimento distinto sem qualquer prevalência de uma sobre as outras. De acordo com os ensinamentos do saudoso Helly Lopes Meirelles (2000), essas três responsabilidades são independentes e podem ser apuradas conjunta ou separadamente.

A condenação criminal implica, entretanto, reconhecimento automático das duas outras, porque o ilícito penal contém o ilícito administrativo e o ilícito civil. Assim sendo, a condenação criminal por um delito funcional importa no reconhecimento, também, de culpa administrativa e civil; mas a absolvição no crime nem sempre isenta o funcionário dessas responsabilidades, porque pode não haver ilícito penal e existirem ilícitos administrativos e civis.

No âmbito do direito processual penal, é oportuna a transcrição da orientação do professor Fernando da Costa Tourinho Filho, que, após citar os sistemas legais referentes às ações penais e civis acerca do mesmo fato, leciona:

\begin{abstract}
No direito pátrio, o sistema adotado é o da independência, com certa mitigação. O preceito legal que norteia todo o ordenamento jurídico pátrio acerca do tema, e também é aplicável às infrações administrativas, é o esculpido no art. 1.525 do Código Civil que, desse modo, preserva a independência de instâncias, de forma atenuada, quando a causa tiver sido definitivamente solucionada na jurisdição penal. (Tourinho Filho, 1986, p. 87).
\end{abstract}

Não há propriamente uma prevalência da instância criminal sobre as outras, mas sim o reconhecimento de que, como no processo penal, vigoram princípios mais extremados na proteção do status libertatis do cidadão, dentre eles o da verdade real; a sentença criminal é aquela que detém presunção absoluta de haver solucionado o conflito com base naquilo que realmente ocorreu, e não por ilações ou ficções jurídico-processuais. Daí a justificativa para as normas dos arts. 63 e 65, ambos do Código de Processo Penal.

Colocadas tais premissas, na década de 80 e início dos anos 90, entendia-se que eram perfeitamente aplicáveis às instâncias criminal, cível e administrativa, destacando-se a questão inserida nos delitos fiscais e contra o sistema financeiro nacional. Naquela época, entendia-se ser possível a não influência do procedimento administrativo (tampouco do seu encerramento) na ação penal em que se debate a prática de ilícito penal.

Esse panorama fora modificado completamente com a edição do artigo 83 da Lei 9.430/96, o qual dispõe que a representação fiscal para fins penais relativa aos crimes contra a ordem tributária definidos nos artigos $1^{\circ}$ e $2^{\circ}$ da Lei 8.137, de 27 de dezembro de 1990, será encaminhada ao Ministério Público, após proferida a decisão final, na esfera administrativa, sobre a existência fiscal do crédito tributário correspondente.

\title{
3 Processo Penal Independente do Término do Procedimento Administrativo
}

Antes da lei que trata dos crimes contra a ordem tributária, era assente que o prévio esgotamento da via administrativa não era condição de procedibilidade para a ação penal. 
As responsabilidades administrativas e criminais eram independentes e autônomas, bastando lembrar que nos delitos fiscais o lançamento apenas declarava e formalizava o crédito tributário existente, ou seja, entendia-se que o ilícito penal existira em período anterior e diante da fiscalização realizada era constatado e devidamente documentado e retratado por meio de auto de infração com o consequente lançamento fiscal. O mesmo raciocínio era válido para os crimes contra o sistema financeiro nacional no que tange à fiscalização levada a efeito pela autarquia própria.

Assim, o posicionamento majoritário era de que o ilícito penal e ao mesmo tempo tributário não é constituído com o lançamento, nos delitos fiscais, mas sim apurado (pois já ocorreu) e apenas será tornado líquido para efeito de sua exigibilidade. É possível, em tese, que seja descoberta conduta que se amolda ao delito de sonegação fiscal sem qualquer procedimento administrativo-fiscal: supondo-se que o crédito tributário esteja prescrito, mas o delito não, diante das penas mais rigorosas previstas na vigente Lei n ${ }^{\circ} 8.137 / 90$. Ninguém sustentaria que a ação penal não poderia ser iniciada e finda independentemente de qualquer responsabilização administrativa.

Ao lado das condições da ação, ditas genéricas (possibilidade jurídica do pedido, legitimidade para agir e interesse de agir), a lei prevê certas condições que subordinam o exercício da ação penal. Assim, por exemplo, as ações penais condicionadas dependem da representação da pessoa designada em lei para que possam ser iniciadas. Confira a precisa lição de Tourinho Filho:

\footnotetext{
Tomemos como exemplo um crime de ameaça. Se o promotor oferece denúncia contra Mévio, pelo fato de haver ameaçado Tício, embora aquele seja parte legítima, porquanto a ação é pública, embora haja exuberantes elementos de convicção quanto ao fato e autoria, vale dizer, não obstante satisfeitas as condições genéricas, o juiz procurará examinar se houve ou não a representação. Realmente. Dispõe o art. 43, III, última parte, do CPP, que a denúncia ou queixa será rejeitada, a despeito de satisfeitas as exigências dos incs. I, II e III, primeira parte, se "faltar condição exigida pela lei para o exercício da ação penal". Por outro lado, o art. 24 do Estatuto Processual Penal proclama que "nos crimes de ação pública, esta será promovida por denúncia do Ministério Público, mas dependerá, quando a lei o exigir (...), de representação do ofendido ou de quem tiver qualidade para representá-lo”. (1986, P. 87).
}

Admitia-se a inexigibilidade de qualquer condição de procedibilidade para o início da ação penal referente aos delitos fiscais ou contra o sistema financeiro nacional, nem mesmo a apresentação da denominada "representação para fins criminais". Assim, cabia ao Ministério Público, ao analisar os elementos de prova existentes, independentemente da fase do procedimento administrativo (ou de sua ausência), formular a opinio delictii, oferecendo denúncia ou pedido de arquivamento, conforme o caso. Confiram-se, por oportuno, alguns julgados:

O procedimento administrativo-fiscal não constituía pressuposto ou condição de procedibilidade da ação penal, ou de instauração de inquérito policial, para apurar o delito de sonegação fiscal.

Quanto aos delitos fiscais, não era unânime, mas prevalecia o entendimento de que conforme o art. 142, do Código Tributário Nacional, o qual dá atribuição à autoridade administrativa de efetuar o lançamento, consolidando o crédito tributário existente desde a ocorrência do fato gerador, determinando o valor do tributo (e, se for o caso, do que deve ser pago, na hipótese de sonegação). Pode ocorrer hipoteticamente que a autoridade fazendária, por lapso ou mesmo por delito funcional, não efetue o lançamento e, portanto, defendia-se que isso não iria impedir o exercício da ação penal, por meio da máquina judiciária.

O oferecimento de impugnação ou a interposição de recurso administrativo suspende a exigibilidade do crédito tributário, mas não a possibilidade de se ingressar com a ação penal correspondente, diante da independência das instâncias. Conforme mencionado, o tributo é 
preexistente ao lançamento - apenas vai ser declarado por este - e, assim, a lesão ao fisco ocorreu quando da prática da conduta lesiva ao erário. Dessa maneira, o bem juridicamente tutelado foi lesado pela conduta do agente, não sendo necessário se aguardar o término do procedimento administrativo-fiscal.

No mesmo diapasão, entendia-se que como o fato gerador do tributo é anterior à atividade de fiscalização desenvolvida pela Administração Pública e, assim, o encerramento do procedimento administrativo seria completamente irrelevante para a configuração do delito, não sendo condição para o início da ação penal.

Ainda sobre o tema, deve ser destacado trecho de artigo doutrinário de Antonio Cláudio Mariz de Oliveira (1995), referente aos delitos denominados econômicos:

\begin{abstract}
Um dado importante revelado pela modificação da natureza do crime tributário, que de crime formal passou a ser um crime material ou de dano, diz respeito à influência da decisão administrativa na esfera penal. Como a conduta material tem por escopo a supressão ou redução de tributos, se no âmbito administrativo for declarada a inexistência do mesmo, não se poderá falar em crime, pois, qualquer ação do agente objetivando atingir os tributos será inócua, pois estes inexistem. (1995, p. 25).
\end{abstract}

É certo que, nos delitos fiscais, a descrição de condutas penalmente reprováveis na Lei $n^{\circ} 8.137 / 90$ pressupõe a redução ou supressão de tributo, sendo que a noção de tributo advém do Direito Tributário e, consequentemente, deve ser buscada na legislação tributária, desde a Constituição Federal até os atos normativos baixados no âmbito do Poder Executivo, e, é claro, o vigente Código Tributário Nacional.

Tal constatação não tem o condão de atribuir às autoridades fiscais o monopólio de definir a existência ou não de crime de sonegação fiscal, por exemplo, mesmo porque incumbirá ao magistrado, na ação penal, apreciar incidenter tantum a questão referente à ocorrência ou não do fato gerador e todos os seus consectários.

A correta interpretação acerca da Lei no 8.137/90 depende do aproveitamento de noções e conceitos de Direito Tributário, que podem ser perfeitamente detectados pelo juiz criminal, não ficando este adstrito à decisão proferida no procedimento administrativo. Zelmo Denari (1996), ao analisar o tema quanto aos delitos fiscais, comentou que, inobstante à autonomia da ação penal enunciada na Súmula 609 do STF, o reconhecimento de exoneração fiscal na esfera administrativa afeta o conteúdo da decisão criminal, visto que o tipo penal do art. $1^{\circ}$ da Lei no 8.137/90 é um crime material.

Não obstante a orientação acima, havia quem defendesse a possibilidade do seu não acatamento, ainda mais considerando que várias poderiam ser as causas de extinção do crédito tributário, como, por exemplo, o pagamento do tributo após o recebimento da denúncia no Processo Penal. Outro exemplo: a decadência ou mesmo prescrição do crédito tributário, sem que tenha ocorrido a prescrição da pretensão punitiva. E, evidentemente, se houver causa para a invalidação da autuação levada a efeito e, consequentemente, a desconstituição do lançamento realizado, o juiz, na condução do processo penal, deverá proferir julgamento absolutório.

Assim, defendia-se o não acolhimento da tese de que a questão tributária no âmbito administrativo seja prejudicial à questão penal. O art. 93 do Código de Processo Penal, ao tratar da denominada questão prejudicial heterogênea, refere-se à competência do Juízo Cível e não da alçada de autoridade administrativa, mas sim judicial.

O próximo tópico demonstrará que a tese esposada acima perdeu força na doutrina e na jurisprudência, culminando com a edição de uma súmula vinculante que condensou o entendimento de que as instâncias administrativa, tributária e penal nos delitos contra a Ordem Tributária são interdependentes. 


\section{O Processo Administrativo Tributário e a sua InfluênCia na ApuraÇão dos Crimes contra a Ordem Tributária}

Conforme se verificou a questão da independência entre as instâncias administrativa e penal - assunto longamente debatido nos tribunais e que culminou com a edição da Súmula $n^{\circ} 609$ do STF - "É pública incondicionada a ação penal por crime de sonegação fiscal", editada na vigência da Lei ${ }^{\circ} 4.729 / 65$ que trazia o crime de sonegação fiscal e que não impunha legalmente o prévio esgotamento da via administrativa como pressuposto para o exercício da ação penal.

Contudo, esta lei foi revogada pela a Lei nº 8.137, de 1990, que não mais fala em sonegação fiscal e sim em crimes contra a ordem tributária. Na definição dos tipos penais deu-se um tratamento diverso à matéria.

Os crimes contra a ordem tributária e outras matérias correlatas foram disciplinados pela Lei $n^{\circ} 8.137 / 90$, que tipifica condutas realizadas pelo contribuinte e por funcionários públicos. Também fixa as penalidades (penas privativas de liberdade ou pecuniárias) ou medidas de segurança. As condutas mais graves são alcançadas pelas regras do direito penal e os crimes contra a ordem tributária preveem não apenas a sanções civis e administrativas, mas também a sanções de natureza penal.

Os crimes contra a ordem tributária ou práticas fraudulentas definidos nos arts. $1^{\circ}$ e $2^{\circ}$ da Lei $n^{\circ} 8.137 / 90$, que visam reduzir, retardar ou suprimir a cobrança dos tributos, possuem o seu tipo legal delimitado por esta legislação específica, mas somente estarão definitivamente constituídos por meio de procedimento administrativo no qual se deva garantir a aplicação dos princípios da legalidade e da ampla defesa, inclusive com a discussão sobre a regularidade da constituição deste crédito e com a garantia de duplo grau.

É unânime na doutrina de que o delito do art. $1^{\circ}$ da Lei n ${ }^{\circ} 8.137 / 90$ é crime material, de dano, para cuja consumação é necessária a produção do resultado previsto no tipo "suprimir ou reduzir tributos". No delito de sonegação fiscal, que era formal, bastava a prática de qualquer das condutas, independentemente do resultado. Até mesmo o delito previsto no art. $2^{\circ}$ da Lei n ${ }^{\circ} 8.137 / 90$, entende-se, majoritariamente, como sendo este de natureza material, pois o caput do art. $2^{\circ}$ estatui que constituem crimes da "mesma natureza" a prática das ações previstas em seus diversos incisos.

Destarte, percebe-se que, conforme a definição legal dos crimes contra a ordem tributária (supressão ou redução de tributos), estes possuem a sua consumação com a efetiva produção desse resultado. Então, consequência lógica é a de que só se pode cogitar em supressão ou redução do tributo após findar-se o procedimento administrativo, que culmina com o lançamento tributário, uma das formas de constituição definitiva do crédito tributário.

Portanto, não há como negar a influência do processo administrativo tributário nos delitos contra a Ordem Tributária, pois é clarividente a existência de uma relação de interdependência das instâncias penais e administrativas no concernente à verificação desses citados crimes. Hodiernamente, é imprescindível a comprovação efetiva do dano ao erário público com a comprovada supressão ou redução do tributo, não sendo suficiente para a instauração da ação penal a mera lavratura do auto de infração.

Nesse viés, o art. 83 da Lei $n^{\circ}$ 9.430/96 dispõe que, para a fiscalização poder encaminhar representação de crime contra a ordem tributária ao Ministério Público, necessário se faz que seja proferida a decisão final na esfera administrativa sobre a exigência fiscal do crédito tributário correspondente. 
Temos que a possibilidade de utilização da sanção penal como forma de coação para o pagamento dos tributos também é severamente questionada ainda mais em um país como o nosso, em que a alta carga tributária é considerada injusta devido à ausência de contraprestação ao quantum arrecadado com tributos diretos e indiretos. A tipificação dos crimes contra a ordem tributária não pode extrapolar a finalidade primordial das sanções criminais, que é a de proteção dos bens jurídicos essenciais ameaçados por determinado comportamento humano.

A mera ausência de pagamento dos tributos pelo contribuinte do qual não se poderia exigir outra conduta ou, de outro modo, a impossibilidade de sua prestação devido a impossibilidades financeiras pelas quais passe o contribuinte, caracterizando estado de necessidade, não pode ser considerada ilícito penal. A punição dessa conduta por meio de uma aplicação de pena privativa de liberdade somente poderá ocorrer se o contribuinte obteve o resultado de redução ou supressão do tributo por meio de condutas ilícitas, previstas expressamente na legislação pátria e se houve o dolo de produzir aquele resultado.

Em matéria tributária, devemos observar ainda que, para que se comprove a existência do crédito tributário passível de execução pela administração pública, deve esse crédito estar regular e definitivamente constituído pelo lançamento e pelo esgotamento dos questionamentos em âmbito administrativo. Ainda devemos nos ater às causas de suspensão, extinção e exclusão do crédito tributário, as quais fazem cessar os efeitos decorrentes desses créditos, bem como às causas extintivas de punibilidade.

Retomando a já citada Súmula 609, saliente-se que, em face do novo panorama jurídico, esta deve ser reformulada, já que a nova lei definidora dos delitos contra a ordem tributária instituiu infrações penais que se classificam como materiais e de dano, com um arcabouço jurídico diverso do existente à época da sonegação fiscal, tipificada pela revogada e obsoleta Lei nº 4.729/65.

Rememore-se que no início da década de 90, o STF já vinha modificando seu posicionamento e, conforme a nova definição legal do ilícito penal tributário, manifestou-se a favor do reconhecimento da interdependência das instâncias penal e administrativa, por meio da concessão da ordem de habeas corpus (HC n ${ }^{0} 71.755-1$ - DJU 4.11.94)².

Verificava-se, portanto, que a jurisprudência já rumava ao encontro dos reclamos da doutrina, que há tempos vem defendendo a influência da esfera administrativa tributária na penal, conclamando a existência de verdadeira prejudicialidade na matéria. Além do Supremo, outros tribunais também já se manifestaram nesse sentido, tais como o Tribunal Regional Federal da 3ª Região (HC no 96.03.060711-8, Rel. Juíza Sylvia Steiner, DJU 9.10.96, p. 76.292); analisou-se que, embora se admitisse independência das instâncias administrativas e penal, o mero auto de infração não é suficiente para deflagrar a ação penal. Vejamos:

\footnotetext{
1. Se a denúncia arrima-se tão somente em autos de infração lavrados pela fiscalização autárquica, e se tais autos de infração foram anulados por decisão judicial, inexiste prova da materialidade delitiva.

2. O princípio da independência das instâncias administrativa e penal não autoriza a que se impute ao contribuinte a prática de crime de natureza fiscal antes mesmo de a administração proceder à regular apuração da existência do débito, ou quando nulo o procedimento administrativo de que resultou a lavratura do auto de infração.

3. Ordem concedida para determinar o trancamento da ação penal.
}

\footnotetext{
${ }^{2}$ A fim de impedir o seguimento da ação penal proposta contra dirigentes de empresa exportadora de madeira, baseado no fato de que a materialidade do fato gerador da obrigação tributária, reclamada pela Fazenda Pública, ainda se encontrava em fase de discussão no âmbito administrativo (Cf. em Direito Penal Tributário - Edmar Oliveira Andrade Filho - Ed. Atlas - ed. 1995 - p. 147).
} 
E no mesmo sentido:

AÇÃO PENAL. Crime tributário, ou crime contra a ordem tributária. Art. $1^{\circ}$ da
Lei n$^{\circ}$ 8.137/90. Delito material. Tributo. Inscrição mediante auto de infração.
Cancelamento por decisão judicial em mandado de segurança. Crédito não lançado
definitivamente. Falta irremediável de elemento normativo do tipo. Crime que se não
tipificou. Trancamento do processo. HC concedido para esse fim. Precedentes. Não se
tipificando crime tributário sem o lançamento fiscal definitivo, não se justifica pendência
de ação penal, quando foi cancelada, por decisão judicial em mandado de segurança,
a inscrição do suposto débito exigido. BRASIL. STF. HC no $81.321 /$ SP, Relator Min.
Cezar Peluso. D.j.u. 15/02/2008.
CRIME. ORDEM TRIBUTÁRIA. INQUÉRITO POLICIAL. PROCESSO
ADMINISTRATIVO FISCAL. Resulta do descumprimento de condição objetiva de
punibilidade a impossibilidade de instauração da ação penal por prática do crime de
sonegação fiscal (crime contra a ordem tributária) e, consequentemente, do próprio
inquérito policial enquanto não houver decisão final sobre a exigência do crédito
tributário (lançamento definitivo do tributo), tal como determinado pelo art. 83 da Lei
no 9.430/1996. No caso, não houve sequer auto de infração, como demonstrado por
certidão, a comprovar inexistir ainda crédito exigível. Precedentes citados do STF: ADI
1.571-1-DF, DJ 30/04/2004; do STJ: RHC 16.994-RS, DJ 28/11/2005. HC 53.033-BA,
Rel. Min. Paulo Medina, julgado em 28/03/2006.

É inquestionável, pois, a interdependência entre as mencionadas instâncias, mas a ação penal por crimes contra a ordem tributária é de natureza pública incondicionada (artigo 15 da Lei $n^{\circ}$ 8.137/90). Esse artigo não foi modificado pelo art. 83 da Lei n ${ }^{\circ}$ 9.430/96, de modo a introduzir uma condição de procedibilidade para o exercício da ação penal.

A representação de que trata o mencionado artigo 83 configura-se como uma espécie de notitia criminis, em que qualquer pessoa poderá provocar a iniciativa do Ministério Público nos crimes descritos na Lei 8.137/90, não sendo esta uma possibilidade exclusiva das autoridades fazendárias (art. 16 da Lei 8.137/90). E tal representação fiscal para fins penais só será encaminhada após o fim do procedimento administrativo em que se apure a constituição definitiva do crédito tributário, pois o bem jurídico só restará hipoteticamente ofendido, quando o tributo é exigível e o contribuinte se nega a pagá-lo.

Desse modo, a conclusão definitiva do procedimento administrativo trará ou não a comprovação da materialidade do crime, consectário lógico da ação do contribuinte.

Vale ressaltar que o Ministério Público não está impedido de oferecer denúncia antes do término deste procedimento. Contudo, o magistrado deverá rejeitar essa denúncia por carência de ação e falta de interesse de agir. Nesses casos, como não houve a comprovação do resultado descrito no tipo penal, inexistirá justa causa para a ação penal, que somente exsurge após a afirmação na instância administrativa de que se constituiu um crédito tributário exigível devido.

Nesse viés, defende-se que o mais acertado, em observância aos princípios da eficiência e da celeridade, seria que o Ministério Público não pudesse oferecer denúncia nos crimes previstos nos artigos $1^{\circ}$ e $2^{\circ}$ da Lei $n^{\circ} 8.137$ e nos artigos 168-A e 337-A do Código Penal, antes do prévio exaurimento da via administrativa.

Tal constatação advém da suspensão da exigibilidade do crédito tributário em razão da pendência do processo administrativo, pois apenas com a decisão final deste é que se obterá certeza acerca do débito tributário. Se essa decorrência não fosse aferida, conforme o entendimento de Hugo de Brito Machado (2004), estaria "admitindo-se o uso da ação penal como instrumento para constranger o contribuinte ao pagamento de tributo que pode não ser devido".

Nessa mesma linha de raciocínio, segue o posicionamento do entendimento do Supremo Tribunal Federal: 
I. EMENTA: I. Crime material contra a ordem tributária (L. 8137/90, art. $1^{\circ}$ ): lançamento do tributo pendente de decisão definitiva do processo administrativo: falta de justa causa para a ação penal, suspenso, porém, o curso da prescrição enquanto obstada a sua propositura pela falta do lançamento definitivo. 1. Embora não condicionada a denúncia à representação da autoridade fiscal (ADINMC 1571), falta justa causa para a ação penal pela prática do crime tipificado no art. $1^{\circ}$ da L. 8137/90 - que é material ou de resultado -, enquanto não haja decisão definitiva do processo administrativo de lançamento, quer se considere o lançamento definitivo uma condição objetiva de punibilidade ou um elemento normativo de tipo. 2. Por outro lado, admitida por lei a extinção da punibilidade do crime pela satisfação do tributo devido, antes do recebimento da denúncia (L. 9249/95, art. 34), princípios e garantias constitucionais eminentes não permitem que, pela antecipada propositura da ação penal, se subtraia do cidadão os meios que a lei mesma the propicia para questionar, perante o Fisco, a exatidão do lançamento provisório, ao qual se devesse submeter para fugir ao estigma e às agruras de toda sorte do processo criminal. (...) HC 81.611 (DJ 13.5.2005) - Relator Ministro Sepúlveda Pertence - Tribunal Pleno.

E ainda a edição da súmula vinculante $\mathrm{n}^{\circ} 24^{3}$, que pacifica inexistirem os crimes elencados nos incisos do art. $1^{\circ}$ da Lei 8.137/90, antes do lançamento definitivo do tributo.

Contudo, vale considerar se em virtude dessa opção legislativa e jurisprudencial não se estaria passando para a sociedade uma sensação de impunidade em relação aos crimes contra a ordem tributária.

Frente a essa hipótese é que se observou ainda bastante polêmica quanto a tais decisões (por exemplo: HC 81611, julgado no dia 10/12/2003) em que o Supremo Tribunal Federal fixou finalmente a sua jurisprudência no sentido de que não pode o Ministério Público promover a ação penal, nos crimes tributários, antes do julgamento definitivo dos processos na via administrativa. O julgamento trouxe várias divergências, gerando decisão não unânime.

Entretanto, assevera Hugo de Brito Machado (2004)4, ao comentar o julgamento do supracitado Habeas Corpus, defendendo que:

O importante, porém, é que afinal prevaleceu a tese que evita seja a acão penal utilizada como instrumento de coacão contra o contribuinte, com o objetivo de impedir que o mesmo conteste, pelas vias legais, a cobrança de tributo indevido. (Grifo nosso).

Vale destacar a importância da influência do processo administrativo fiscal na esfera penal, pois, até mesmo o Ministro Joaquim Barbosa, que teve seu voto vencido na decisão do HC 81611, reconheceu a relevância da interdependência entre tais instâncias, conforme se vê através do comentário do ilustre doutrinador Hugo de Brito Machado (2004):

Ressalte-se finalmente que o Ministro Joaquim Barbosa, mesmo tendo afinal aderido
à tese da Ministra Ellen Gracie, afirmou "a necessidade de tratamento harmônico
da matéria nas esferas administrativa, penal e civil." Pois "a desarmonia entre
elas poderia acarretar a indesejável coincidência da condenação penal seguida
do reconhecimento da inexistência do débito fiscal na esfera administrativa."
(Grifo nosso).

Assevere-se que o presente trabalho foi motivado pela relevância da questão que envolve a validade jurídica do uso da ação penal como instrumento de coação para obrigar o contribuinte a pagar tributos, sem direito de questionar a legalidade e até mesmo a existência destes (se realmente o crédito tributário fora definitivamente constituído).

\footnotetext{
${ }^{3}$ Não se tipifica crime material contra a ordem tributária, previsto no art. $1^{\circ}$, incisos I a IV, da Lei no 8.113/90, antes do lançamento definitivo do tributo. (Súm. Vinculante $24 \mathrm{STF}$ ).

${ }^{4}$ MACHADO, Hugo de Brito. Ação penal como instrumento de coação nos crimes tributários. 2004. Disponível em: $<$ http://www.hugomachado.adv.br>. Acesso em: 07 out. 2012.
} 
Tal questionamento fora respondido e solucionado a contento pelas decisões da Suprema Corte (precedentes: HC 81611, HC 85185, HC 86120, HC 83353, HC 85463 e HC 85428), culminando com a edição da Súmula Vinculante $n^{\circ} 24$ : (STF Súmula Vinculante $n^{\circ} 24$ - DJE no 30/2010 - Tribunal Pleno de 02/12/2009 - DJE no 232, p. 1, em 11/12/2009 - DOU de 11/12/2009, p. 1 -Tipificação - Crime Material Contra a Ordem Tributária - Lançamento do Tributo):

Não se tipifica crime material contra a ordem tributária, previsto no art. $1^{\circ}$, incisos I a IV, da Lei $\mathrm{n}^{\circ} 8.137 / 90$, antes do lançamento definitivo do tributo.

Desta feita, nosso posicionamento é no sentido de que o Supremo Tribunal Federal agiu com bastante presteza e eficiência no que tange à resposta oferecida à comunidade jurídica, demonstrando a imprescindibilidade da conclusão do procedimento administrativo tributário para a tipificação de crime material contra a ordem tributária.

Este posicionamento da Suprema Corte revela o habitual zelo aos princípios basilares do Direito Penal, e contribui positivamente para a construção, no Brasil, de um Estado Democrático de Direito e de Direito Democrático. É por este caminho que todos nós, operadores do Direito, devemos seguir, sempre em busca da eficiência, celeridade, equidade e justiça, a caminho da verdadeira democracia.

\section{Conclusão}

Pelo exposto, resulta clara a influência determinante do procedimento administrativo tributário na apuração e processamento dos crimes contra a ordem tributária, já que é necessário o lançamento definitivo do tributo para que se tipifiquem os crimes materiais contra ordem tributária, previstos na Lei 8.137/90.

Esse entendimento é vinculante, ou seja, todo o Judiciário deve se pautar por ele, sob pena de o magistrado que proceder diversamente ser submetido a uma reclamação constitucional (previsão do instituto no art. 102, I, “l”, e no art. 105, I, "f”, da Constituição Federal de 1988).

Desse modo, deve-se aguardar o término do procedimento administrativo a fim de ser possível o início do procedimento criminal, pois, restou comprovado que a mera vista da autuação fiscal (representação da Autoridade Fiscal ou a lavratura do auto de infração) não induz justa causa penal e, além disso, lesaria fortemente o princípio constitucional da ampla defesa previsto no artigo $5^{\circ}$, IV da Constituição Federal de 1988.

Enfim, concluímos que o procedimento administrativo tributário exerce influência determinante nos crimes contra a Ordem Tributária, visto que há uma verdadeira relação de interdependência das instâncias criminais e administrativas no que tange à existência, suspensão e extinção da punibilidade de tais crimes.

Hodiernamente, já não basta a mera realização formal da conduta descrita no tipo. Faz-se mister que além das condutas típicas se produza o resultado lesivo ao erário público, sendo imprescindível a comprovação efetiva do dano, qual seja: a supressão ou redução do tributo, que será aferida apenas com o término do processo tributário, por meio do lançamento definitivo do tributo e sua posterior inadimplência.

\section{REFERÊNCIAS}

ANDRADE FILHO, Edmar Oliveira. Direito penal tributário. 3. ed. São Paulo: Atlas, 1995.

BARBOSA, Evandro Paes. Direito tributário perante os tribunais. Campo Grande/MS: Solivros, 2000. 
DENARI, Zelmo. Infrações Tributárias e Delitos Fiscais. 2. ed. São Paulo: Saraiva, 1996.

DI PIETRO, Maria Sylvia Zanella. Direito Administrativo. 4. ed. São Paulo: Atlas, 1994.

MACHADO, Hugo de Brito. Ação Penal como Instrumento de Coação nos Crimes Tributários. 2004. Disponível em: <http://www.hugomachado.adv.br> $>$. Acesso em: 07 out. 2005.

. Crimes Contra a Ordem Tributária. São Paulo: Atlas, 2008. Em 30/03/2012.

. Julgamento Administrativo e Ação Penal nos Crimes Contra a Ordem Tributária.

2003. Disponível em: < http://www.hugomachado.adv.br>. Acesso em: 11 abr. 2012.

. Inexigibilidade de Outra Conduta nos Crimes Contra a Ordem Tributária. 2004.

Disponível em: <http://www.hugomachado.adv.br>. Acesso em: 10 abr. 2012.

MEIRELLES, Hely Lopes. Direito Administrativo Brasileiro. 14. ed. São Paulo: Revista dos Tribunais, 2000.

MENDES, Ronnie Freitas. A suspensão e a extinção da punibilidade nos crimes contra a ordem tributária. In: Âmbito Jurídico, Rio Grande, 64, 01/05/2009. [Internet] Disponível em: $<$ www.ambitojuridico.com.br/site/index.Php?N link=revista artigos leitura\&artigo

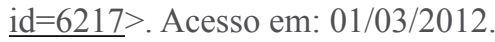

OLIVEIRA, Antonio Cláudio Mariz de. "Reflexões sobre os crimes econômicos". Revista Brasileira de Ciências Criminais. São Paulo, nº 11, p. 99-100, Jul./Set. 1995.

SEGUNDO, Hugo de Brito Machado. Anotações da aula de processo tributário realizadas na Faculdade Farias Brito em 2008.

SILVA, Jorge Medeiros da. Direito Penal Especial. São Paulo: Revista dos Tribunais, 1981.

SOUZA, Nelson Bernardes de. Crimes Contra a Ordem Tributária e Processo

Administrativo. Jus Navigandi, Teresina, ano 2, nº 8, 3 mar. 1997. Disponível em: < $\underline{\text { http://jus. }}$ com.br/revista/texto/1311>. Acesso em: 29 mar. 2012.

TOURINHO FILHO, Fernando da Costa. Processo penal. 9. ed. São Paulo: Saraiva, 1986. V. 2.

WATANABE, Ippo; PIGATI JÚNIOR, Luiz. Dicionário de Decisões Tributárias. São Paulo: Juarez de Oliveira, 2001.

\title{
TAX ADMINISTRATIVE PROCESS IN BRAZIL AND ITS INFLUENCE ON RELATED CRIMINAL OFFENSES
}

\begin{abstract}
The present article discusses the interdependence of criminal and administrative bodies as regards the prosecution of offenses against Brazil's Tax Order system, under Federal Law $n^{\circ} 9.430$ of december 27, 1996 and through reviews of both the doctrine and jurisprudence, to demonstrate the relevance of connecting these instances.
\end{abstract}

Keywords: Interdependence. Administration. Crimes. Tax law.

Data de recebimento: fev/2013 - Data de aprovação: abr/2013 